\title{
Association of Technical Institutions
}

D APERS read before the annual summer meeting of the Association of Technical Institutions, held at Brighton on June 22-23, included "Apprenticeship and the Irish Apprenticeship Act", by Mr. R. R. Butler, of the Aston Technical College; "National Scheme of Foundry Education", by Mr. J. G. Pearce, director of the British Cast Iron Research Association; and "The Function and Operation of Junior Instruction Centres", by Mr. Valentine A. Bell. Mr. Bell's paper insisted that the work of the Juvenile Instruction Centres has consistently followed the general purpose of preventing "demoralisation likely to result from unemployment" and "facilitating the absorption of boys and girls into employment as soon as opportunity may occur". Mr. Bell, who has visited these centres in various parts of the country, dealt with criticism levelled against them. $\mathrm{He}$ did not fail to stress difficulties such as those of staff recruitment (since "there was no guarantee as to how long the centres would remain open, it was difficult to find men who had permanent jobs to take up this new work"), but his answer to the criticism so often made, namely, little good can be done where the average length of stay per student is only three weeks, is to the point : "Those who merely study statistics are easily inveigled into making rash statements. . . I I may have had 10,000 through my Centre during the past four years. Thousands may have found work within a week, but hundreds have stayed with me for six months or more, yet the average may work out at only four weeks."

Very closely allied to Mr. Bell's paper was an address given by Mr. F. N. Tribe, of the Ministry of Labour, who dealt with the educational provisions of the Unemployment Bill. He pointed out that the Royal Commission on Unemployment Insurance recommended that the gap between the school-leaving age and the age of entry into insurance should be bridged by lowering the age of entry into unemployment insurance to correspond with the statutory school-leaving age. The recommendation avoided any stereotyping of age fourteen years as the proper age for leaving and suggested that contributions should be credited in respect of voluntary full-time education, and that attendance at a course of instruction should be a normal condition for the receipt of benefit by anyone. less than eighteen years of age. These conditions have been accepted by the Government.

Mr. R. R. Butler indicated that while laws governing apprenticeship are in operation in Germany, Denmark, Hungary, South Africa, New Zealand, Ontario and the Irish Free State, no similar national system has been considered desirable in England. It is clear that, under rationalised conditions in industry, it is no longer possible for a master craftsman to educate his apprentice. Under conditions of mechanisation, the duties of apprenticeship fall increasingly on technical colleges. $\mathrm{He}$ urged an increase in full- and part-time day technical colleges and an extension of the junior trade schools on a national basis. These steps become the more necessary if, in England, we are not prepared, like the Irish Free State (Act of 1931) to adopt a legal system of apprenticeship. In any scheme, however, training for specialised jobs will be of less importance than training for adaptability to changing processes.

Mr. J. G. Pearce also underlined the importance of adaptability of mind and the power to reason correctly about the new facts and circumstances which are continually arising. The old distinction between the man of theory and the man of practice, he said, is fast disappearing. He went on to describe a national scheme of education for the founding industry. A school for training those who have already experience in the industry to be managers, foundry engineers, chemists and metallurgists is to be opened at Birmingham Central Technical College in October 1935 if sufficient students are forthcoming.

\section{Annual Conference of the Museums Association}

$\mathrm{T}$ HE forty-fifth annual Conference of the Museums Association was held at Bristol on July 2-7, by invitation of the Lord Mayor and Corporation. The meetings were held in the Museum and Art Gallery, but the University authorities very kindly granted the delegates additional facilities. The Conference was very well attended and some two hundred and thirty members of the Association met under the presidency of Dr. Cyril Fox, director of the National Museum of Wales.

In his presidential address, Dr. Fox, in the first place, dealt with the progress of the Association during the year and the great developments at home and in the Dominions due to the generosity of the Carnegie Corporation of New York and the Carnegie Trust in Great Britain. He commented also on the firm and practical basis upon which the diploma scheme and the educational policy of the Association now rest. The main part of his address, however, was occupied by a plea for a National Folk Museum in Great Britain. After describing a typical Continental open-air museum (that of Skansen, Stockholm) he emphasised its advantages and cultural effect. Dr. Fox also stressed the additional establishment of regional open-air museums to illustrate local aspects of general culture. $\mathrm{He}$ urged províncial curators to collect in the meantime the fast-disappearing furnishings and implements of local interest.

Following the presidential address, Dr. R. E. M. Wheeler opened a discussion on folk museums, in which he divulged that the Departmental Committee, set up according to the recommendations of the Royal Commission on National Museums and Galleries, has come to the conclusion that the National. Folk Musoum should be in London, about 10-15 acres in size, and should consist of a museum containing folk-material and an open-air coherent village-group illustrative of English country life before the Industrial Revolution.

In the afternoon Mr. J. E. Barton interested and am'ised the delegates with a paper on "The Education of Public Taste" and Mr. H. W. Maxwell described the steps that have been taken during his directorship to modernise the Bristol Museum and Art Gallery. 
The whole of Wednesday morning was devoted to more scientific subjects. Dr. F. S. Wallis, speaking on "The Popularisation of Geology", suggested simpler labelling, more life-reconstructions of extinct animals, and less truly systematic arrangement of specimens. Dr. F. J. North gave an excellent account of map making and the importance of map collections, especially those of the middle and later part of last century. Prof. A. E. Trueman, of Bristol, wound up the morning with a paper on "Science and the Public Museum" in which he urged a greater curatorial interest in working things illustrating the physical sciences, especially astronomy. This paper was much appreciated and evoked a good discussion which seemed to indicate that quite a number of delegates have little knowledge of recent improvements in science museums.

Thursday morning was occupied by the annual general meeting, but afterwards seven members of a delegation of the Association to the recent American Museums Conference at Toronto gave their impressions gained upon the tour. They were informative and entertaining, and showed a respect for much American museum technique and even for such diverse things as American petrol stations and cemeteries. In the afternoon the delegates were conducted round the various University departmental museums by their honorary curators.

The morning of the last day was devoted to short papers by Prof. L. P. W. Renouf, of Cork, on "Stamps as Educational Exhibits", by Mr. Percy Grimshaw, of the Royal Scottish Museum, on the newly-arranged Children's Gallery in that Museum, and by an excellent demonstration by the Gaumont British Film Company of the uses of the cinema in the museum. All the meetings were well attended though there was probably less general discussion this year than is usual. It only needs to be added that there was a full trade exhibition staged in the Royal West of England Academy. Dr. Cyril Fox was re-elected president of the Association, and it was decided to accept the Belgian Government's kind invitation to hold the next conference in Brussels.

\section{University and Educational Intelligence}

LoNDon.-The Court has accepted a tender of $£ 362,579$ from Messrs. Holland and Hannen and Cubitts, Ltd., for the superstructure of the first of the buildings to be erected on the University's site in Bloomsbury. A condition of the contract will be the use throughout of materials obtained from sources within the British Empire. The date for completion is March 25, 1936.

ST. Andrews.-The Court has appointed Dr. A. M. Taylor to be lecturer in natural philosophy, and Mr. $\mathrm{R}$. Jackson to be lecturer in philosophy, in the United College.

The Sir Henry Jones Memorial Committee has offered to the University a sum of about $£ 100$ to provide annual prizes in the Department of Moral and Political Philosophy. Prof. Henry Jones held the chair of logic and metaphysies from 1891 until 1894.

The degree of D.Sc has been conferred upon R. C. Menzies for a thesis on the application of thallium compounds in organic chemistry, and upon James Stirling for a thesis entitled "A Study of Flowering in Heterostyled and Allied Species".
THE following awards for the year 1934-35 have been made by the Salters' Institute of Industrial Chemistry and approved by the Court of the Salters' Company:-Fellowships have been renewed to:J. D. Rose, of Jesus College, Oxford ; C. W. Woolgar, of King's College, London. Fellowships have been awarded to :-G. Broughton, of East London College ; D. E. Wheeler, of the University of Bristol ; L. R. Barrett, of Lincoln College, Oxford. The Salters' Institute has also awarded one hundred and thirtysix grants-in-aid to young men and women employed in chemical works to facilitate their further studies.

THE Science Scholarships Committee of the Royal Commission for the Exhibition of 1851 has made the following appointments to Overseas Scholarships for 1934 on the recommendation of the institutions named : Canada. MeGill University, Montreal : Dr. E. Solomon, for research in physical chemistry at the University of Manchester, and Dr. A. H. Snell, for research in physics at the University of California. Queen's University, Kingston : Mr. W. E. Bennett, for research in physics at the University of Cambridge. University of Toronto : Dr. L. B. Pett, for research in biochemistry at the National Institute for Medical Research, London. Australia. University of Adelaide : Mr. L. A. T. Ballard, for research in plant physiology at the University of Cambridge. University of Melbourne : Mr. L. H. Smith, for research in organic chemistry at the University of Oxford, and Mr. D. P. R. Petrie, for research in physics at the University of Cambridge. New Zealand. University of New Zealand: Mr. H. Service, for research in geology at the Imperial College of Science and Technology, London. Irish Free State. University of Dublin : Joyce C. Hill, for research in zoology at the Strangeways Research Laboratory, Cambridge.

\section{Science News a Century Ago}

\section{The Obelisk of Luxor}

In the Mechanics Magazine of July 12 and 19 , 1834 , is an interesting account of the arrangements made for the transport to France from Egypt, a country "once great and flourishing, but now desolate and forsaken", of the famous Obelisk of Luxor. The plans for its transport were entrusted to the distinguished naval engineer, Jean Baptiste Lebas (17971873), who had been a student at the Ecole Polytechnique. Under his direction a special vessel was built at Toulon, the crew of which consisted of 120 seamen and 12 artisans. Commanded by Lieut. Vernniac, the vessel sailed from Toulon on April 15, 1831, arrived at Alexandria on May 3 and proceeding up the Nile, reached Luxor on July 12, when her rigging and fittings were removed. With her stern ashore, as the waters subsided she settled in the sand and sand was piled high around her sides. A section of the stern was then removed and an inclined plane was constructed to the Temple 1,500 ft. away. The obelisk was then encased in a wooden shell, one side of which was worked smooth and greased, and by means of a number of tackles and capstans the obelisk, weighing about 240 tons, was slowly lowered and drawn down the inclined plane and placed in the ship. These operations were completed by December 19, when the vessel was released from the sand and re-rigged, and on December 25 proceeded down the river. The obelisk was set up in the Place de la Concorde, Paris, by Lebas in 1836. 